\title{
The Problem of Access to Government Procurement Markets in the Indonesia-European Union CEPA Regarding the Obligation to Use Domestic Products in Indonesia
}

\author{
Syukri, ${ }^{1 *}$ Huala Adolf, ${ }^{2}$ Prita Amalia ${ }^{3}$ \\ 1.Graduate Student at Faculty of Law, Universitas Padjadjaran, Indonesia, Analyst of Bilateral and Regional at \\ National Public Procurement Agency, Indonesia \\ 2.Professor at Faculty of Law, Universitas Padjadjaran, Indonesia \\ 3.Lecturer \& Researcher at Faculty of Law, Universitas Padjadjaran, Lecturer \& Researcher at Faculty of Law, \\ Universitas Padjadjaran, Indonesia \\ * E-mail of the corresponding author: Syukrisomad@gmail.com
}

\begin{abstract}
Indonesia and the European Union are currently negotiating the Indonesia-European Union Comprehensive Economic Partnership Agreement (I-EU CEPA) on Government Procurement Chapter which aims to open market access based on the principle of non-discrimination. However, the principle of non-discrimination proposed by the European Union has different provisions from the regulation on the use of domestic products in Indonesia because the use of domestic products is required in the government procurement and is discriminatory against foreign products and suppliers. This study aims to explain whether these different arrangements will eliminate the obligation to use domestic products in Indonesia if the I-EU CEPA is agreed. The results of this study indicate that if the principle of non-discrimination of the I-EU CEPA on Government Procurement Chapter is agreed, it will not immediately eliminate the obligation to use domestic products in Indonesia because the principle of non-discrimination only applies to covered procurement. Indonesia can implement transitional measures while still enforcing regulations on the use of domestic products in the government procurement by giving time after entry into force as an adjustment effort in order to increase the competitiveness of domestic products against foreign products and the threshold permitted for foreign suppliers.
\end{abstract}

Keywords: Market Access, Non-discrimination Principle, I-EU CEPA, Domestic Products, Government Procurement

DOI: $10.7176 / \mathrm{JLPG} / 118-11$

Publication date: February $28^{\text {th }} 2022$

\section{Introduction}

Government Procurement - procurement of goods, construction work, consultancy services and other services required by the government are an important aspect in international trade and an important part for the government of a country in carrying out various public activities. Robert D. Anderson and Sue Arrowsmith in their study stated that the importance of government procurement has been enhanced by the increasing importance of public infrastructure investment and other procurement activities as an aspect of world economic activity in the context of the economic crisis and as a consequence of continued growth with increasing demand for infrastructure not only in developed countries but also in developing countries. ${ }^{1}$ This is because the procurement market itself is around $10-15 \%$ of the Gross Domestic Product (GDP) globally and is also important because it is seen from the benefits obtained by both domestic and foreign stakeholders in increasing transparency, integrity and competition. ${ }^{2}$

Procurement transactions worldwide account for 7.1\% of global GDP. In various developed countries such as the United States and European Union countries, no less than 13-17\% of the GDP is allocated for government procurement. ${ }^{3}$ More than $30 \%$ of the State Budget in Indonesia is allocated annually for government procurement. In the 2019 Indonesian State Budget, which is IDR 2,163.9 Trillion, for the government procurement is allocated IDR $1,133.4$ Trillion or $52.4 \%$. Of this amount, 97,998 tender packages with a value of IDR 265 trillion were transacted through electronic procurement (e-tendering), and 314 thousand packages with a value of IDR 54 trillion were transacted through direct shopping (e-Purchasing) through electronic catalogs. The rest is a procurement scheme that has not been accommodated through the electronic system. ${ }^{4}$

The Indonesian government is faced with market access problems due to increased state spending related to

\footnotetext{
${ }^{1}$ Sue Arrowsmith and Robert D. Anderson, (2011), The WTO Regime on Government Procurement: Challenge and Reform, Cambridge University Press, p. 4.

${ }^{2}$ WTO, "WTO and Government Procurement", available at https://www.wto.org/english/tratop_e/gproc_e/gproc_e.htm.

${ }^{3}$ OECD stats at http://stats.oecd.org/.

${ }^{4}$ Directorate for Procurement Planning, Monitoring and Evaluation NPPA/LKPP, "2019 National Procurement Profile"”, monev-nglkpp.go.id.
} 
government procurement. On various international occasions, the Government of Indonesia is often asked to open market access for government procurement for partner countries, both within the framework of bilateral agreements in the Free Trade Agreement (FTA)/Comprehensive Economic Partnership Agreement (CEPA) and in the framework of the World Trade Organization Agreement on Government Procurement (WTO GPA). ${ }^{1}$ Then, to respond to this request, the Government of Indonesia began to consider options to open market access for government procurement in Indonesia with partner countries, one of which was the European Union in the form of Indonesia - the European Union Comprehensive Economic Partnership Agreement (I-EU CEPA).

The text of the Government Procurement Chapter in the I-EU CEPA submitted by the European Union refers to the WTO GPA. WTO Agreements consist of Multilateral and Plurilateral Agreements. ${ }^{2}$ For the Multilateral Agreement, all WTO member countries are obliged to ratify it, while for the Plurilateral Agreement it is not mandatory (voluntary-based). The WTO GPA is a plurilateral agreement, which means that this agreement is not mandatory for all WTO members, but only binds the signatories. The WTO GPA rules were negotiated through the Uruguay Round in 1994, and came into force on January 1, 1996. However, not all WTO member countries have signed or ratified the WTO GPA rules, including Indonesia. Indonesia currently has observer status since 2012. This WTO GPA rule has an important role as a legal foundation in various issues of procurement by cross-border government either in bilateral or multilateral agreement framework because generally the WTO GPA is the reference text for Government Procurement in free trade agreements between countries in a CEPA or FTA. ${ }^{3}$

Until the 11th round of negotiations I-EU CEPA in November 2021, National Public Procurement Agency (NPPA/LKPP) as the lead negotiator in the Govenrment Procurement Chapter has completed almost the entirety of the draft agreement text. However, there are still several issues in the draft text that have not been resolved because they require a decision from the government and the legislature, and are not under the authority of NPPA, one of which is non-discrimination. In essence, the principle of non-discrimination requires equal treatment for international countries that carry out trading activities so as to create fair and equitable trade practices. $^{4}$

The principle of non-discrimination has different arrangements with Indonesian laws and regulations, including: 1) Law Number 3 of 2014 concerning Industry 2) Government Regulation Number 29 of 2018 concerning Industrial Empowerment; 3) Presidential Regulation Number 16 of 2018 as amended by Presidential Regulation Number 12 of 2021 concerning Government Procurement; 4). Minister of Industry Regulation 02/MIND/PER/1/2014 concerning Guidelines for the Use of Domestic Products in Government Procurement. Some of these regulations require government agencies to use domestic products and/or give price preferences to domestic suppliers and discriminate against goods or services and foreign suppliers. For this reason, a study is needed on whether these different arrangements will eliminate the entire obligation to use domestic products in Indonesia if the non-discrimination principle of the I-EU CEPA on Government Procurement Chapter is agreed upon or there are exceptions in the I-EU CEPA regarding the scope of the agreed procurement (covered procurement) and transitional measures while still enforcing regulations on the use of domestic products in government procurement.

\section{Differences in Regulation between the Non-Discrimination Principle in the I-EU CEPA on Government Procurement Chapter and the Regulation on the Use of Domestic Products in Indonesia}

The Indonesian government has begun to consider options to open market access for government procurement in Indonesia with partner countries, one of which is the agreement with the European Union in the I-EU CEPA framework. The term agreement tends to be used for bilateral agreements and limited to multilateral agreements, ${ }^{5}$ with a substance that is smaller in scope than the material regulated in the Treaty or Convention. ${ }^{6}$ The term agreement is legally included in the international agreement. ${ }^{7}$

The potential of the I-EU CEPA cooperation opportunity will certainly be able to support the improvement of the Indonesian economy and to fulfill national interests for Indonesia and the European Union. The scoping paper which was started in 2012 is the first step taken by Indonesia and the European Union to determine the scope and depth of commitments to be negotiated by the two parties. One part of the scoping paper is Public Procurement which contains the following points:

\footnotetext{
${ }^{1}$ Richo Andi Wibowo, (et.al), (2018), Kajian Dampak Pembukaan Akses Pasar Pengadaan Barang/Jasa Pemerintah Dalam GPA WTO, IEU CEPA dan IJEPA Terhadap Regulasi Dalam Negeri, NPPA/LKPP RI, p. 4.

${ }^{2}$ Multilateral agreements are contained in annexes 1,2, and 3 of the WTO Agreement, plurilateral agreements are contained in annex 4 of the WTO Agreement

${ }^{3}$ Richo Andi Wibowo, (et.al), Op. Cit., p. 12

${ }^{4}$ Huala Adolf, (2016), Hukum Perdagangan Internasional: Prinsip-Prinsip dan Konsepsi Dasar, $1^{\text {st }}$ Ed, Cet. 7, RajaGrafindo Persada, Jakarta, p. 1-2.

${ }^{5}$ Boer Mauna, (2000), Hukum Internasional Pengertian, Peran dan Fungsi dalam Dinamika Global, Alumni, Bandung, p. 92.

${ }^{6}$ Yoyon M Darusman, (2016), Konvensi Internasional Pelaksanaan dan Pengawasannya, Ed.1, Hers Printing, Tangerang Selatan, p. 78.

${ }^{7}$ Mochtar Kusumaatmadja dan Etty R. Agoes, (2003), Pengantar Hukum Internasional, ${ }^{\text {st }}$ Ed, Edisi Kedua, Alumni, Bandung, p. 119.
} 
1. The Agreement will aim to include disciplines on transparency in public procurement, including challenge procedures, and market access opportunities, while taking account of the need for transitional measures.

2. The Agreement should achieve improvements in market access on the basis of the principles of non discrimination and national treatment.

3. Procurement of goods, services and public works will be included in the negotiations, as well as procurement by central and sub-central levels, state control identities and monopolies, especially those operating in the utilities sectors.

Based on the Joint Scoping Paper I-EU CEPA above, one of the scopes of this agreement in the Government Procurement Chapter is "Improvement in market access on the basis of principles of nondiscrimination and national treatment", with commodities to be opened are "goods, services, and public works" for the government procurement at the "central and sub-central levels, state controlled entities and monopolies, especially utilities sectors". The Scoping Paper became the initial basis for Indonesia and the European Union to conduct I-EU CEPA negotiations. Although the Scoping Paper I-EU CEPA is non-binding, it has a strategic function for the negotiation process and for discussing future substance. For this reason, the European Union submitted the substance of the text of the draft I-EU CEPA by including a non-discrimination principle clause according to the WTO GPA Revised.Government Procurement was excluded from the provisions of the GATT and GATS multilateral agreements and later the WTO GPA was agreed as a plurilateral agreement, so for the first time, Indonesia negotiated the basic non-discrimination obligations, namely national treatment and most favored nation for the procurement in accordance with the threshold by the central government entities of the WTO-GPA signatory countries. This provision thus eliminates discrimination against suppliers originating from abroad which benefits domestic suppliers.

NPPA as an institution in charge of implementing the development, formulation, and determination of government procurement policies has been appointed to represent the Indonesian government in negotiating government procurement provisions in various FTAs/CEPAs. Until the 11th round of negotiations for the I-EU CEPA in November 2021, the NPPA as the lead negotiator in the Government Procurement Chapter has successfully completed $90 \%$ of the draft agreement text. However, there are still several issues in the draft text that have not been resolved because they require a decision from the government and the legislature, and are not under the authority of the NPPA, one of which is non-discrimination. The principle of non-discrimination stated in Article IV: Revised WTO GPA and draft I-EU CEPA for Government Procurement Chapter are as follows:

General principles

Non-Discrimination

1. With respect to any measure regarding covered procurement, each Party, including its procuring entities, shall accord immediately and unconditionally to the goods and services of the other Party and to the suppliers of the other Party offering such goods or services, treatment no less favourable than the treatment the Party, including its procuring entities, accords to its own goods, services and suppliers.

2. With respect to any measure regarding covered procurement, a Party, including its procuring entities, shall not:

(a) treat a locally established supplier less favourably than another locally established supplier on the basis of the degree of foreign affiliation or ownership; or

(b) discriminate against a locally established supplier on the basis that the goods or services offered by that supplier for a particular procurement are goods or services of the other Party. ${ }^{1}$

In Article IV:1 of the draft I-EU CEPA, with respect to any actions included in the covered procurement, each Party (Indonesia and the European Union), including the entity or agencies implementing the procurement, must immediately and unconditionally agree to goods and services from other Parties (Indonesia or the European Union) and to suppliers from other Parties (Indonesia or the European Union) who offer these goods or services, treatment is not less favorable (equal to, not better or worse) than treatment given by the Party, including the entity or agencies implementing the procurement, to domestic goods, services, and suppliers. Thus, Article IV:1 of the draft I-EU CEPA prohibits discriminatory treatment by parties, both against goods, services, and domestic providers or to goods, services, and suppliers from other member countries.

Furthermore, in Article IV: 2 of the draft I-EU CEPA, in relation to any actions included in the covered procurement, a Party, including the entity or agencies implementing the procurement, is prohibited from: (a) treating suppliers established legally; local less well than other locally established suppliers based on the degree of foreign affiliation or ownership; or (b) discriminates against suppliers established locally on the basis that the goods or services offered by the suppliers for certain procurement are goods or services from other Parties. Thus, Article IV: 2 of the draft I-EU CEPA states that the state party must also ensure that the procurement

\footnotetext{
1 Teks WTO GPA Revised, Agreement on Government Procurement (as amended on 30 March 2012) available at https://www.wto.org/english/docs e/legal e/rev-gpr-94 01 e.htm, draft text of I-EU CEPA on Government Procurement proposed by the European Union is without prejudice available at https://trade.ec.europa.eu/doclib/press/index.cfm?id=1620, draft text I-EU CEPA on Government Procurement submitted by the Union Europe to Indonesia sourced from NPPA.
} 
implementing entity or agencies do not take discriminatory actions against domestic suppliers who have foreign affiliation or ownership and against suppliers in the country whose products or services offered are from other member countries.

Although this principle is the basic guideline in formulating the WTO GPA Revised and I-EU CEPA for the Government Procurement Chapter, this principle is not absolutely applied to all policies taken by member countries. A number of WTO member countries still use their national rules in conducting government procurement to achieve domestic policy objectives, such as the use of local products. However, the nondiscrimination principle of the I-EU CEPA has a different regulatory substance from the government procurement arrangements in Indonesia, especially with regard to the use of domestic products. These differences include the following:

1. Law Number 3 of 2014 regarding Industry

Law Number 3 of 2014 regarding Industry has different arrangements with the principle of nondiscrimination, especially in articles 86,87 and 88 along with the implementing regulations that regulate the obligation to use domestic products in the government procurement implemented by state institutions and special treatment in the form of price preference to domestic suppliers. This provision is a form of discrimination that is prohibited in the draft I-EU CEPA on Government Procurement Chapter and the WTO GPA Revised.

2. Government Regulation Number 29 of 2018 regarding Industrial Empowerment

Government Regulation Number 29 of 2018 regarding Industrial Empowerment in articles 57, 61, 62, 63, and 64 which regulates the obligation to use domestic products in the government procurement for government agencies with the use of the state budget required in the preparation of documents for government procurement and special treatment in the form of price preferences for domestic suppliers who have a domestic component level presentation which has different arrangements with the principle of nondiscrimination, because it is a form of discrimination that is prohibited in the I-EU CEPA on Government Procurement Chapter and the WTO GPA Revised.

3. Presidential Regulation Number 16 of 2018 regarding Government Procurement

Article 4 (b) and (d), Article 5 (f), Article 19 paragraph (1) letters a and b, Article 66, and Article 67 paragraph (1) Presidential Regulation Number 16 of 2018 regarding Government Procurement has different arrangements with the principle of non-discrimination I-EU CEPA and WTO GPA Revised which prohibits discrimination against foreign products and participation of foreign suppliers in the government procurement.

4. Regulation of the Minister of Industry Number 02/M-IND/PER/1/2014 regarding Guidelines for the Use of Domestic Products in Government Procurement

Article 2 paragraph (2), Article 3, Article 7, Article 10, Article 11, Article 15, Article 16, Article 46 Regulation of the Minister of Industry Number 02/M-IND/PER/1/2014 regarding Guidelines for the Use of Domestic Products in Government Procurement which regulate the obligation to use domestic products in the process of procurement which have been implemented since the planning, implementation and supervision have different arrangements with the principle of non-discrimination, because it is a form of discrimination that is prohibited in -EU CEPA on Government Procurement Chapter and WTO GPA Revised.

Thus, the principle of non-discrimination has different regulations with regulations on the use of domestic products in Indonesia. The regulation requires government agencies to use domestic products and/or to give price preferences to domestic suppliers who have a certain number of achievements at the local content and company benefit weight in the process of government procurement carried out since the procurement plan by the Budget User, in implementation of procurement by the Procurement Service Unit, and supervision by internal and external supervisory officers. Procurement of imported goods can be carried out, in the event that the goods cannot be produced domestically or the volume of domestic production is not able to meet the needs. This provision is a different arrangement from the principle of non-discrimination, because it is a form of discrimination that is prohibited in the I-EU CEPA on Government Procurement Chapter and WTO GPA Revised.

Huala Adolf summarizes three solutions to overcome the problem of differences in national rules between one country and another in international trade transactions, namely: a) there is an agreement between countries not to apply their national law. Instead they only apply international trade law to regulate relations between trade laws; b) if the rules of international trade law do not exist and or are not agreed upon by one of the parties, the national law of a particular country can be used. The method of determination is through the application of the principle of choice of laws agreed upon by the parties as set forth in international contracts. c) Carry out legal unification and harmonization of substantive rules in international trade law. This method is quite effective because it avoids conflicts between the legal systems adopted by each country. The unification of law includes the abolition and replacement of types of law in an effort to achieve uniformity. Meanwhile, legal harmonization 
only aims to find uniformity or common ground for the fundamental principles of the various existing legal systems (which will be harmonized). ${ }^{1}$ Related to these differences in regulation, there are legal implications for the non-discrimination principle of the I-EU CEPA on Government Procurement Chapter if applied in Indonesian national law, especially regarding regulations for the use of domestic products in Indonesia. More will be explained in the next point of regret.

\section{The Application of Non-Discrimination Principle of the I-EU CEPA on Government Procurement Chapter Does not Eliminate the Obligation to Use Domestic Products in Indonesia as a Whole}

There are different arrangements between the non-discrimination principle in the I-EU CEPA in the Government Procurement Chapter and the regulation on the use of domestic products in Indonesia, a decision is needed to reject or apply the non-discrimination principle to the I-EU CEPA according to the clause in the WTO GPA. The positive side of rejecting the principle of non-discrimination is that regulations on the use of domestic products can be protected and Indonesia's position as an observer of the WTO GPA can be protected, but rejecting the principle of non-discrimination has an impact on the possibility that there will be no I-EU CEPA because the principle of non-discrimination is one of the main objectives of the European Union. This does not directly solve the problem because in negotiations there is a single undertaking principle or commonly known as nothing is agreed until everything is agreed, that all chapters must be agreed, even though almost all issues in the chapter (eg Trade in Goods, Services and Intellectual Property Rights) have been discussed agreed, but if there is one issue that has not been agreed upon (eg Government Procurement) then the entire agreement cannot be signed and must wait for the completion of the pending issues. In this case, if the Government Procurement is not agreed, then there is no I-EU CEPA. The European Union emphasizes that the Chapter on Government Procurement will not be agreed if there is no market access based on the principle of non-discrimination.

On the other hand, there is a positive side to the application of the principle of non-discrimination in the IEU CEPA in the Government Procurement Chapter, Indonesia can implement a number of risk mitigation strategies for the impact of not implementing the use of domestic products, but protection of domestic products is only temporary. It should be noted that if you open market access by applying the principle of nondiscrimination, it does not mean that the use of domestic products with a percentage of the level of local content will be abolished in their entirety. Only procurement that is included in covered procurement (contract value is above the threshold and the list is only applied to agreed government agencies) I-EU CEPA is applied on the principle of non-discrimination. Indonesia can make a strategy by excluding some procurement and agencies to remain with the obligation to use domestic products. However, this is limited to covered procurement agreed upon by Indonesia and the European Union. Procurement through other schemes such as for construction work is allowed for foreign suppliers if the threshold is 1 Trillion and above, according to Presidential Regulation Number 16 of 2018 as amended by Presidential Regulation Number 12 of 2021 regarding Government Procurement.

In addition, if the I-EU CEPA is agreed, Indonesia can implement transitional measures while still enforcing regulations on the use of domestic products by giving time after entry into force as an adjustment effort in the context of increasing product competitiveness in the market country to foreign products as well as the threshold allowed for foreign suppliers. However, if it does not open market access by refusing to apply the principle of non-discrimination, then Indonesia can still maintain the obligation to use domestic products but there is no I-EU CEPA

The NPPA as the lead negotiator for the I-EU CEPA on Government Procurement Chapter provides input that if the principle of non-discrimination of the I-EU CEPA on Government Procurement is agreed upon, then Indonesia needs to conduct various studies related to the potential of Indonesian products and Indonesian suppliers who are able to compete in the European Union procurement market. Then it is necessary to identify the types of goods or services required by Indonesian Government institutions that can be fulfilled by European Union suppliers, map the needs for procurement of goods or services from the European Union, implement transitional measures in the form of providing offsets and threshold values for procurement packages committed to market access. Furthermore, it is also necessary to draft regulations to accommodate the results of the I-EU CEPA agreement.

According to the author, if Indonesia and the European Union agree on the principle of non-discrimination in the I-EU CEPA on government procurement chapter, then there will be implications for Indonesian national law, especially regarding regulations for the use of domestic products in Indonesia, the provisions of which require the use of domestic products in government procurement and discriminates against foreign products and suppliers but does not directly eliminate the obligation to use domestic products in government procurement because the I-EU CEPA agreement is bilateral and applies only to the European Union and is limited to covered procurement. If the I-EU CEPA is agreed upon, then Indonesia and the European Union, must provide mutually

${ }^{1}$ Huala Adolf, Hukum Perdagangan Internasional, Op. Cit., p. 30. 
beneficial treatment (equal to, not better or worse), not discriminate against goods, services, and providers from both countries. Indonesia and the European Union must also ensure that procurement implementing entities or agencies do not take discriminatory actions against domestic suppliers who have foreign affiliation or ownership and against domestic suppliers whose products or services are offered.

Various forms of transitional measures that are often used by developing countries include the time period to continue to give price preferences to domestic suppliers, the policy on the percentage of use of domestic products in the government procurement for each contract, thresholds of tenders opened for foreign suppliers to protect domestic small and medium enterprises, technical assistance, obligation to open domestic branches and others.

Vietnam as a country with the same membership status as Indonesia in the WTO GPA as an observer, but has agreed on a CEPA with the European Union, covered procurement Vietnam is limited to Central Level of Government, Sub-Central Level of Commitment as well as several Utility Sector (state-owned enterprises, universities and hospitals) listed in Vietnam's Final Market Access Offer on Government Procurement. ${ }^{1}$ In detail, Vietnam's strategy with the European Union on the Vietnam-EU CEPA is as follows:

Table 1: Vietnam's Final Market Access Offer on Government Procurement dalam Vietnam-EU CEPA.

\begin{tabular}{|c|c|c|c|c|c|c|}
\hline \multirow[t]{3}{*}{ Period } & \multirow{2}{*}{\multicolumn{2}{|c|}{$\begin{array}{l}\text { Central of } \\
\text { Government } \\
\text { All the ministries, the social } \\
\text { security office as well as two } \\
\text { other entities equivalent to } \\
\text { ministries (Committee on } \\
\text { Ethnic Minority Affairs; and } \\
\text { Government Inspectorate) }\end{array}$}} & \multirow{2}{*}{\multicolumn{2}{|c|}{$\begin{array}{l}\begin{array}{l}\text { Sub-Central level of } \\
\text { Government }\end{array} \\
\text { Two Major Cities: Hanoi } \\
\text { and Ho Chi Minh City }\end{array}$}} & \multicolumn{2}{|c|}{ Other Covered Entities } \\
\hline & & & & & $\begin{array}{l}\text { Two utility-rel } \\
\text { branches of the } \\
\text { operator EVN } \\
\text { transport and di } \\
\text { the nationwide } \\
\text { two major uni } \\
\text { research institu } \\
\text { hospitals direct } \\
\text { of the Ministry }\end{array}$ & $\begin{array}{l}\text { ted SOEs (i.e. the } \\
\text { national electricity } \\
\text { n charge of power } \\
\text { tribution and VNR, } \\
\text { railway operator); } \\
\text { ersities; two major } \\
\text { es and } 34 \text { public } \\
\text { under the control } \\
\text { f Health }\end{array}$ \\
\hline & $\begin{array}{l}\text { Goods and } \\
\text { Services }\end{array}$ & $\begin{array}{l}\text { Construction } \\
\text { Services }\end{array}$ & $\begin{array}{l}\text { Goods } \\
\text { and } \\
\text { Services }\end{array}$ & $\begin{array}{l}\text { Construction } \\
\text { Services }\end{array}$ & $\begin{array}{l}\text { Goods and } \\
\text { Services }\end{array}$ & $\begin{array}{l}\text { Construction } \\
\text { Services }\end{array}$ \\
\hline $\begin{array}{l}\text { at entry } \\
\text { into force }\end{array}$ & $\begin{array}{l}1,500,000 \\
\text { (SDR) }\end{array}$ & $\begin{array}{l}40,000,000 \\
(\mathrm{SDR})\end{array}$ & $\begin{array}{l}3,000,000 \\
\text { (SDR) }\end{array}$ & $\begin{array}{l}40,000,000 \\
(\mathrm{SDR})\end{array}$ & $\begin{array}{l}3,000,000 \\
\text { (SDR) }\end{array}$ & $\begin{array}{l}40,000,000 \\
(\mathrm{SDR})\end{array}$ \\
\hline $\begin{array}{l}\text { After } \\
\text { transition } \\
\text { period } 15 \\
\text { years }\end{array}$ & $\begin{array}{l}130,000 \\
(\mathrm{SDR})\end{array}$ & $\begin{array}{l}5,000,000 \\
(\mathrm{SDR})\end{array}$ & $\begin{array}{l}1,000,000 \\
\text { (SDR) }\end{array}$ & $\begin{array}{l}15,000,000 \\
(\mathrm{SDR})\end{array}$ & $\begin{array}{l}1,000,000 \\
(\mathrm{SDR})\end{array}$ & $\begin{array}{l}15,000,000 \\
(\mathrm{SDR})\end{array}$ \\
\hline
\end{tabular}

Notes: 1 SDR = IDR. 20.132 (February 4, 2022).

Furthermore, Vietnam protects the use of domestic products by implementing transitional measures against offsets. The WTO GPA, I-EU CEPA and EU-Vietnam CEPA define offsets as follows: "Offset means any condition or undertaking that encourages local development or improves a Party's balance-of-payments accounts, such as the use of domestic content, of domestic suppliers, the licensing and transfer of technology, investment, counter-trade and similar action or requirement". ${ }^{2}$

The use of offsets is a provision that is not allowed but can be excluded for a certain time by carrying out transnational measures. Article offset in WTO GPA, I-EU CEPA, EU-Vietnam CEPA: "With regard to covered procurement and subject to the relevant Annex pertaining to this Chapter, a Party, including its procuring entities, shall not seek, take account of, impose or enforce any offset"3

Then, Annex C EU-Vietnam CEPA, Vietnam protects the use of domestic products by implementing transitional measures against offsets for 18 (eighteen) years. Offset: Notwithstanding Article.X (Offset), Vietnam is allowed to seek, take account of, impose or enforce any form of offsets at any stage of a procurement as follows: Upon the entry into force of this Agreement, Vietnam may request offsets in any form, including price preference program, up to 40 per cent of the contract value, going down to 30 per cent after 10 years until the end of the 18th year. For greater certainty, procuring entities shall indicate the existence of offsets in the notice of intended procurement and make it detailed in the tender documentation ${ }^{4}$.

The transitional measures against offsets implemented by Vietnam in the EU-Vietnam CEPA are not permanent, after 18 (eighteen) years have passed, the use of domestic products is not mandatory if the European

\footnotetext{
${ }^{1}$ Annex 9c European Union -Vietnam Comprehensive Economic Partnership Agreement.

${ }^{2}$ Article 1 Paragraph (i) WTO GPA Revised, Article 1 Paragraf (10) EU-Vietnam CEPA, Article 1 Paragraph (10) draft text I-EU CEPA.

${ }^{3}$ Article 4 paragraph (6) WTO GPA Revised, Article 1 Paragraph (10) EU-Vietnam CEPA, Articlel 4 paragraph (9) draft text I-EU CEPA

${ }^{4}$ Annex 9c European Union -Vietnam Comprehensive Economic Partnership Agreement, p. 32.
} 
Union suppliers enter the government procurement market in Vietnam which is covered by covered procurement. Transitional measures against offsets are allowed in international trade agreement negotiations. In Vietnam there are many regulations that are different from the WTO GPA rules, such as in government procurement, where there is a preference policy for domestic suppliers who use products originating from Vietnam in the government procurement process. Vietnam sees it as a different regulation and does not conflict with the principle of nondiscrimination because it serves a different purpose.

Indonesia can follow Vietnam's example by asking for a time after entry into force to make adjustments to the regulations on the use of domestic products according to the principle of non-discrimination. For this length of time, it is necessary to study transitional measures with relevant stakeholders because the readiness of suppliers in Indonesia is different from suppliers in Vietnam. During this period, it is important for domestic suppliers to improve the competitiveness of their products against foreign products. Furthermore, with the implementation of regulations for the use of domestic products, Indonesia may propose transitional measures for the use of offsets in the form of preference for domestic suppliers and the threshold allowed for foreign suppliers. Indonesia can determine the list of sectors offered to the European Union in covered procurement.

\section{Conclusion}

The principle of non-discrimination consisting of most favored-nation treatment and national treatment in the IEU CEPA on Government Procurement Chapter has different regulations with regulations on the use of products in government procurement in Indonesia because government agencies are required to use domestic products, domestic providers are given price preferences and discrimination against foreign goods, services and providers. The difference in regulation does not immediately eliminate the obligation to use domestic products in Indonesia as a whole because the principle of non-discrimination only applies to covered procurement. Indonesia can implement transitional measures while still enforcing regulations on the use of domestic products in government procurement by giving time after entry into force as an adjustment effort in order to increase the competitiveness of domestic products against foreign products as well as the threshold allowed for foreign suppliers.

\section{References \\ Books}

Ade Maman Suherman, (2000), Hukum Perdagangan Internasional: Lembaga Penyelesaian Sengketa WTO dan Negara Berkembang. $1^{\text {st }}$ Ed., Sinar Grafika, Jakarta Timur.

Astim Riyanto, (2003), World Trade Organization (Organisasi Perdagangan Dunia). $1^{\text {st }}$ Ed., PT Yapemdo, Bandung.

Bahder Johan Nasution, (2016), Metode Penelitian Ilmu Hukum. Mandar Maju, Bandung.

Boer Mauna, Hukum Internasional Pengertian, Peran dan Fungsi dalam Dinamika Global, Alumni, Bandung, 2000.

Huala Adolf, (2006), Hukum Perdagangan Internasional, $1^{\text {st }}$ Ed., Raja Grafindo Persada, Jakarta.

Huala Adolf, (2004), Hukum Perdagangan Internasional: Prinsip-Prinsip dan Konsepsi Dasar, Rajawali Press, Bandung.

Jawahir Tantowi dan Pranoto Iskandar, (2006), Hukum Internasional Kontemporer. $1^{\text {st }}$ Ed., Refika Aditama, Bandung.

John Rawls, (2006), “A Theory of Justice, London: Oxford University press”, yang sudah diterjemahkan dalam bahasa Indonesia oleh Uzair Fauzan dan Heru Prasetyo, Teori Keadilan, Pustaka Pelajar, Yogyakarta.

Malcom N. Shaw QC, (2013), "Hukum Internasional", Terjemahan M.N. Shaw, (2006), "International Law”, Cambridge University Press, Nusa Media, Bandung.

Mochtar Kusumaatmadja dan Etty R. Agoes, (2003), Pengantar Hukum Internasional, $1^{\text {st }}$ Ed., Edisi Kedua, Alumni, Bandung.

Prita Amalia dan Garry Gumelar Pratama, (2020), Hukum Perjanjian Perdagangan Internasional (Kerangka Konseptual dan Ratifikasi di Indonesia). $1^{\text {st }}$ Ed., CV. Keni Media, Bandung.

Peter Mahmud Marzuki, (2013), Penelitian Hukum, Cet. 8. Edisi Revisi. Kencana Prenada Media Group, Jakarta. Muhammad Abdulkadir, (2004), Hukum dan Penulisan Hukum, Citra Aditya Bakti, Bandung.

Nico Ngani, (2012), Metodelogi Penelitian dan Penulisan Hukum. Pustaka Yustisia, Yogyakarta.

Sefriani, (2015), Peran Hukum Internasional Dalam Hubungan Internasional Kontemporer, PT. Raja Grafindo Persada, Jakarta.

Sue Arrowsmith and Robert D. Anderson, (2011), The WTO Regime on Government Procurement: Challenge and Reform, Cambridge University Press.

Suratman dan Philips Dillah, (2015), Metode Penelitian Hukum, Alfabeta, Bandung.

Yoyon M Darusman, (2016), Konvensi Internasional Pelaksanaan dan Pengawasannya,. $1^{\text {st }}$ Ed., Hers Printing, Tangerang Selatan. 


\section{Journals}

Damos Dumoli Agusman, (2008), "Status Hukum Perjanjian Internasional dalam Hukum Nasional Republik Indonesia: Tinjauan dan Perspektif Praktik Indonesia”, Jurnal Hukum Internasional, Vol. 5, No. 3.

Delegation of European Union, (2011), Invigorating the Indonesia-European Union Partnership Towards a Comprehensive Economic Partnership Agreement.

Estu Hayu Dewanti, (2012), "Persyaratan Kandungan Lokal (Local Content Requirements) di Indonesia dan Kaitannya dengan Perjanjian Internasional di Bidang Investasi”, Yuridika Journal : Vol. 27, No. 3.

Hikmahanto Juwana, (2019) "Kewajiban Negara dalam Proses Ratifikasi Perjanjian Internasional: Memastikan Keselarasan dengan Konstitusi dan Mentransformasikan ke Hukum Nasional”, Undang: Jurnal Hukum, Vol. 2, No. 1.

Florence Naegelen and Michel Mougeout, (1998), "Discriminatory Public Procurement Policy and Cost Reduction Incentives", Journal of Public Economics Elsevier Science, Vol. 67.

Joko Priyono, (2013), "Prinsip Most Favoured Nations dan Pengecualiannya dalam World Trade Organization (WTO)", Jurnal Masalah-Masalah Hukum Universitas Diponegoro, Jilid 42, No. 4.

Juladies H. S. Watupongoh, (2016), "Tinjauan Yuridis Atas Persetujuan Pada Perjanjian Internasional Melalui Ratifikasi”, Lex et Societatis, Vol. IV., No. 2.

Margaret Liang, (2006), "Government Procurement at Gatt/WTO: 25 Years of Plurilateral Framework", Asian Journal of WTO \& International Health Law and Policy, Vol. 1, No. 2.

Scientific Study

NPPA/LKPP, (2011) Kajian Pengadaan Barang/Jasa dalam Pengembangan Iklim Usaha Nasional, Directorate for Development of Business Climate and International Cooperation .

Richo Andi Wibowo, (et.al), (2018), Kajian Dampak Pembukaan Akses Pasar Pengadaan Barang/Jasa Pemerintah Dalam GPA WTO, I-EU CEPA dan IJEPA Terhadap Regulasi Dalam Negeri, NPPA/LKPP RI.

Poppy Sulistyaning Winanti, (et.al), (2018), Kajian Kajian Dampak Ekonomi Liberalisasi Pengadaan Barang/Jasa Pemerintah dalam Kerangka I-EUCEPA Terhadap Industri Domestik, NPPA/LKPP RI.

Indonesian Laws and Regulations

Republik of Indonesia. Law on Industry. Law Number 3 of 2014. LNRI Tahun 2004 Nomor 4. TLNRI Nomor 5492.

-------, Law regarding Pengesahan Agreement Establishing The World Organization. Law Number 7 of 1994. LNRI Tahun 2007 Nomor 57. TLNRI Nomor 3556.

-------, Government Regulation regarding Industrial Empowerment.PP Number 29 Tahun 2018. LNRI Tahun 2018 Nomor 101. TLNRI Nomor 6220.

-------, Presidential Regulation regarding Government Procurement. Perpres Nomor 16 Tahun 2018. LNRI Tahun 2018 Nomor 33.

\section{International Instrument}

Agreement Establishing The World Trade Organization.

Draft Articles of Indonesia-European Union Comprehensive Partnership Agreement

Government Procurement Agreement of World Trade Organization

Joint Scoping Paper for an EU - Indonesia Comprehensive Partnership Agreement.

EU Directive 2014/24/EU on Public Procurement and repealing Directive 2004/18/EC available at http://eurlex.europa.eu/legal-content/EN/TXT/?uri=CELEX:02014L0024-20160101

EU Directive 2014/25/EU on procurement by entities operating in the water, energy, transport and postal services sectors and repealing Directive 2004/17/EC available at http://eurlex.europa.eu/legalcontent/EN/TXT/?uri=CELEX:02014L0025-20160101

EU Directive 2014/23/EU on the award of concession contracts available at http://eurlex.europa.eu/legalcontent/EN/TXT/?uri=CELEX:02014L0023-20160101,

Vienna Convention on the Law of Treaties, 1969.

Internet

Directorate for Procurement Planning, Monitoring and Evaluation NPPA/LKPP, "2019 National Procurement Profile"", monev-ng-lkpp.go.id.

Ministry of Trade of the Republic of Indonesia, Invigorating The Indohjmghnesia - EU Partnership: Towards a Comprehensive Economic Partnership Agreement, available at https://ditjenppi.kemendag.go.id/index.php/bilateral/eropa/uni-eropa.,

Ministry of Trade of the Republic of Indonesia, Latar Belakang Indonesia-European Union Comprehensive Economic Partnership Agreement, available at https://ditjenppi.kemendag.go.id/index.php/bilateral/eropa/uni-eropa

Ministry of Trade of the Republic of Indonesia, Manfaat Indonesia-European Union Comprehensive Economic Partnership Agreement, available at https://ditjenppi.kemendag.go.id/index.php/bilateral/eropa/uni-eropa. 
Ministry of Trade of the Republic of Indonesia, Perundingan Pertama I-EU CEPA (Kick-Off Meeting) available at https://ditjenppi.kemendag.go.id/index.php/bilateral/eropa/uni-eropa.

OECD stats availale at http://stats.oecd.org/.

European Commission, The texts proposed by the EU for the trade deal with Indonesia, available at https://trade.ec.europa.eu/doclib/press/index.cfm?id=1620, European Commission, Report of the round of negotiations for a Free Trade Agreement between the European Union and Indonesia, available at http://trade.ec.europa.eu/doclib/press/index.cfm?id=1620.

WTO, General overview of WTO work on government procurement, available at https://www.wto.org/english/tratop_e/gproc_e/overview_e.htm.

WTO, "WTO and Government Procurement", availabe at: https://www.wto.org/english/tratop_e/gproc_e/gproc_e.htm.

WTO, Text of the Agreement on Government Procurement, available at https://www.wto.org/english/tratop_e/gproc_e/gpa_1994_e.htm 